\title{
Identification and genetic diversity of Spodoptera frugiperda in Lampung Province, Indonesia
}

\author{
PUJI LESTARI ${ }^{1}$, ADRIYANA BUDIARTI ${ }^{2}$, YUYUN FITRIANA ${ }^{1, \bullet}$, FX. SUSILO $^{1}$, I GEDE SWIBAWA ${ }^{1}$, \\ HAMIM SUDARSONO ${ }^{1}$, RADIX SUHARJO ${ }^{1}$, AGUS M. HARIRI ${ }^{1}$, PURNOMO $^{1}$, NURYASIN ${ }^{1}$, SOLIKHIN $^{1}$, \\ LESTARI WIBOWO ${ }^{1}$, JUMARI $^{3}$, MAMAN HARTAMAN ${ }^{4}$ \\ ${ }^{1}$ Department of Plant Protection, Faculty of Agriculture, Universitas Lampung. Jl. Soemantri Brojonegoro No. 1, Bandar Lampung 35141, Lampung, \\ Indonesia. Tel.: +62-721-704946, Fax.: +62-721-770347, "email: yuyun.fitriana@fp.unila.ac \\ ${ }^{2}$ Department of Agrotechnology, Faculty of Agriculture, Universitas Lampung. Jl. Soemantri Brojonegoro No. 1, Bandar Lampung 35141, Lampung, \\ Indonesia \\ ${ }^{3}$ Laboratory of Crop and Horticultural Plant Protection Gading Rejo. Jl. Raya Wates, Gading Rejo, Pringsewu 35372, Lampung, Indonesia \\ ${ }^{4}$ Crop and Horticultural Plant Protection Agency of Lampung Province. J1. ZA. Pagar Alam No. 1, Bandar Lampung 35132, Lampung, Indonesia
}

Manuscript received: 1 March 2020. Revision accepted: 26 March 2020.

\begin{abstract}
Lestari P, Budiarti A, Fitriana Y, Susilo FX, Swibawa IG, Sudarsono H, Suharjo R, Hariri AM, Purnomo, Nuryasin, Solikhin, Wibowo L, Jumari, Hartaman M. 2020. Identification and genetic diversity of Spodoptera frugiperda in Lampung Province, Indonesia. Biodiversitas 21: 1670-1677. Spodoptera frugiperda is one of the most recent invasive and destructive insect pest in Indonesia. Recently, it has been reported that this pest was found in some cornfield areas in Sumatera, including Lampung. This research was performed to confirm the presence of $S$. frugiperda in Lampung Province by collecting and identifying larvae of Spodoptera found in the field as well as investigation on the genetic diversity of the established populations and to observe the damage caused by this pest on cornfields in the Lampung Province. The observation was conducted from February-April 2019 at four locations (districts) representing corn-producing areas in Lampung, namely Lampung Selatan, Lampung Timur, Pesawaran and Pringsewu, each location comprising five plots. The plot is a cornfield with plants aged 14-40 days after planting. Twenty plants were randomly chosen in every plot as plant samples to collect the Spodoptera larvae and to calculate the absolute plant damage caused by the larvae. The absolute plant damage was analyzed by dividing the attacked plants with total plants observed and multiply by $100 \%$. Identification of the Spodoptera larvae was performed based on morphological characters and molecular techniques using sequence analysis of Cytochrome c Oxidase subunit I (COI) gene. The result confirmed that the larvae found in the corn field in Lampung were $S$. frugiperda. There was no nucleotides variation in the sequence of COI gene among $S$. frugiperda found in Lampung Province (Lampung Selatan, Lampung Timur, Pesawaran and Pringsewu) as well as $S$. frugiperda that was found in corn from foreign countries. The absolute plant damage caused by this pest in the four districts of Lampung was in the range of $26.50-70 \%$.
\end{abstract}

Keywords: Corn, damage intensity, genetic diversity, identification, Spodoptera frugiperda

\section{INTRODUCTION}

Spodoptera frugiperda (J.E. Smith, 1797) (Lepidoptera: Noctuidae) is an insect native from tropical America (Neotropical region is preferred) and it has become a serious pest on maize in several countries (Luginbill 1928). In early 2016, S. frugiperda was initially detected in several countries in central Africa namely Benin, Nigeria, Sao Tome and Principe, and Togo (Goergen et al. 2016; Insecticide Resistance Action Committee 2018). Further, it dispersed to more than 30 countries in Africa (Prasanna et al. 2018) and confirmed in the whole of mainland Africa except Lesotho and The Island States (Insecticide Resistance Action Committee 2018).

In 2018, S. frugiperda has been reported attacking maize in Karnataka, India (Sharanabasappa et al. 2018), and in the same year, it was reported attacking maize in Myanmar (Yee et al. 2019), Thailand, and Srilanka (IPPC 2018). Recently, it has spread to almost all American and Asian countries (IPPC 2018), including Indonesia (Trisyono et al. 2019; Maharani et al. 2019). S. frugiperda was firstly reported in Indonesia in early 2019 attacking a cornfield at the northern part of Sumatera Island (Nonci et al. 2019) and now it has been spread in some other cornfield areas such as Lampung (Trisyono et al. 2019) as well as the west part of Java (Maharani et al. 2019) and Sulawesi (Nur Edy, Tadulako University, Personal communication). This pest insect has been reported causing significant yield losses on corn worldwide, for example, Brazil (34\% of yield losses) (Lima et al. 2009), Zimbabwe (11.57\% of yield losses) (Baudron et al. 2019), Kenya (more than $30 \%$ of yield losses) (Groote et al. 2020) and India (33\% of yield losses) (Balla et al. 2019).

Spodoptera frugiperda has been reported to have more than 100 host plants (Sharanabasappa et al. 2018). Based on literature review and additional surveys, Montezano et al. (2018) revealed that there are 353 host plants of $S$. frugiperda found in Brazil, from 76 families, mainly Poaceae, Asteraceae, and Fabaceae. This pest is preferred maize as their host (Hruska 2019), however, it is also commonly found in ryegrass, wheat, sorghum, millets (Pitre et al. 1983; Hruska 2019) and sugar cane (Srikanth et 
al. 2018; Chormule et al. 2019; Song et al. 2020). Moreover, S. frugiperda is sporadically important in cotton, soybean, and vegetables (Pitre et al. 1983; Hruska 2019).

There is a large genetic variability on $S$. frugiperda species (Monnerat et al. 2006; Belay et al. 2012; Clark et al. 2017), and many biotypes that are morphologically identical, but presenting physiological differences (Pashley 1988; Nagoshi and Meagher 2004). Pashley (1986) concluded that genetic variations within $S$. frugiperda are not affected by its host plant, but are permanently established in the strains. The genetic variability within $S$. frugiperda was supposedly caused by the geographical distribution of this pest (Monnerat et al. 2006; Belay et al. 2012; Clark et al. 2007).

Lampung Province is one of the major maize producing areas in Indonesia. Therefore, the corn producers in Lampung should be aware of the spread and outbreak of $S$. frugiperda. The availability of maize in every growing season in Lampung provides a high potential for fastwidespread and outbreak of this pest. This research was conducted to confirm the presence of $S$. frugiperda in Lampung, to investigate the genetic diversity and to observe the damage caused by this pest on corn.

\section{MATERIALS AND METHODS}

\section{Spodoptera larvae collection}

Spodoptera larvae were taken from the field for identification purposes. The larvae were collected from 4 locations representing corn-producing area in Lampung, namely Lampung Selatan, Lampung Timur, Pesawaran and Pringsewu. The caterpillars were put into plastic jar $(14 \mathrm{~cm}$ of diameter) and kept it alive for further identification.

\section{Identification}

Identification was performed in order to confirm the presence of $S$. frugiperda in Lampung Province. The taxonomic concept for the species as considered here is given by Dumas et al. (2015). The identity of the larvae was revealed using morphological characteristics and sequence analysis based on Cytochrome c Oxidase subunit I (COI) gene.

\section{Morphological identification}

The obtained larvae were observed under stereomicroscope (Leica EZ4HD, Singapore) with a magnification 8-30 $\mathrm{X}$ on some characteristics such as $\mathrm{Y}$ shape on the head, pinacula on eight tergum, proleg bearing crochet, mandible setae, etc. Identification was conducted referring to the determination keys of Godfrey (1987).

\section{Molecular identification}

\section{DNA extraction}

Abdomen of the larvae ( $1 \mathrm{~cm}$ of length) was put in a 1.5 $\mathrm{mL}$ tube, and put $5 \mu \mathrm{L}$ Proteinase $\mathrm{K}(10 \mathrm{mg} / \mathrm{mL})$. The sample containing $300 \mu \mathrm{L}$ of TNES buffer (Tris $\mathrm{HCl} 1 \mathrm{M}$ (pH 7.5), $\mathrm{NaCl} 5 \mathrm{M}$, EDTA $0.5 \mathrm{M}$, ddH $\mathrm{de}_{2} \mathrm{O}$, and 20\% SDS) were pounded and incubated for three hours at $60{ }^{\circ} \mathrm{C}$. After incubation, $85 \mu \mathrm{L}$ of $5 \mathrm{M} \mathrm{NaCl}$ was added and centrifuged at $14.000 \mathrm{rpm}$ for 10 minutes. The supernatant $(400 \mu \mathrm{L})$ was transferred into another $1.5 \mathrm{~mL}$ tube. As much as 400 $\mu \mathrm{L}$ of $100 \%$ Ethanol (in a cold condition) was added and centrifuged at $14.000 \mathrm{rpm}$ for 5 minutes. The supernatant was discharged from the tube. Five hundred microliter of $70 \%$ Ethanol was added and centrifuged at $14.000 \mathrm{rpm}$ for 5 minutes. The supernatant was discharged and air-dried the pellets for 24 hours. Totally, $50 \mu \mathrm{L}$ TE buffer $\left(1^{\text {st }}\right.$ Base, Malaysia) was added and stored at- $4{ }^{\circ} \mathrm{C}$ for further used. The centrifugation was performed using microcentrifuge Microspin12 (Biosan, Latvia).

\section{DNA amplification}

DNA amplification was performed in order to obtain COI gene sequences of the barcode region. DNA barcodes were amplified by primer LCO 1490 and HCO 2198 (Folmer et al. 1994). Amplification was performed using Sensoquest Thermal Cycler Machine (Germany). PCR was conducted in total volume $25 \mu \mathrm{L}$ consist of $1 \mu \mathrm{L}$ DNA template, 12,5 $\mu \mathrm{L}$ master mix (2x MyTaq HS Red Mix, Bioline, USA), $1 \mu \mathrm{L}$ of each primer LCO 1490 and HCO 2198 (Folmer et al. 1994) at $10 \mu \mathrm{M}$ of concentration and 9,5 $\mu \mathrm{L}$ distilled water. One cycle of initiation was performed at $95{ }^{\circ} \mathrm{C}$ for five minutes continued with 30 cycles of denaturation for at $95{ }^{\circ} \mathrm{C}$ one minute, primer annealing at $54{ }^{\circ} \mathrm{C}$ for one minute, primer extension at 72 ${ }^{\circ} \mathrm{C}$ for one minute. One cycle of elongation was performed at $72{ }^{\circ} \mathrm{C}$ for five minutes. The PCR product were checked by electrophoresed in $0.5 \%$ agarose gel with $1 \mu \mathrm{L}$ ethidium bromide $(\mathrm{EtBr} ; 10 \mathrm{mg} / \mathrm{mL})$ at 55 volt for 70 minutes. The result was visualized under DigiDoc UV transilluminator (UVP, USA).

\section{Sequencing and phylogenetic analysis}

The PCR product was sent to $1^{\text {st }}$ Base Malaysia for sequencing. The results of sequencing were analyzed using Bio Edit program ver. 7.2.6 for windows (Hall 1999). The sequences and then submitted to Basic Local Alignment Search Tool (BLAST) (https://blast.ncbi.nlm.nih.gov/Blast.cgi) and Barcode of Life and Datasystem (BOLD) (http://boldsystems.org/index.php/IDS_OpenIdEngine) to reveal its possible identity. The phylogenic tree was constructed by Mega 7 program for Windows (Kumar et al. 2016) using Unweighted-pair Group Method with Arithmetic means (UPGMA). Reference strains of $S$. frugiperda, S. litura, S. exigua, S. mauritia as well as Stenocranus pacificus (Acc. no. LC412751.1) as outgroup was obtained from NCBI (https://www.ncbi.nlm.nih.gov/).

\section{Genetic diversity analysis}

The sequence result was aligned by clustalW using Mega 7 for windows (Kumar et al. 2016) and compared with the $C O I$ sequences of $S$. frugiperda retrieved from NCBI (https://www.ncbi.nlm.nih.gov/). Percentage of similarity was analyzed by calculating total similar nucleotide divided with total nucleotide observed and multiply by $100 \%$. 


\section{Observation on plant damage caused by $\boldsymbol{S}$. frugiperda}

Observation was performed at the same period and the same locations as where were the larvae collected, each location comprising five plots. Purposive random sampling was used to determine the plot to be observed. The plot is a cornfield with plants that are aged 14-40 days old after planting. Twenty corn plants were randomly chosen in each plot as sample. Observation was performed on the attacked plants. Absolute plant damage was measured by calculating total of attacked plants divided with total plants observed and multiply by $100 \%$. Observation was also performed on the presence of egg mass on the leaf surface and the plant damage symptoms caused by the larvae of $S$. frugiperda.

\section{RESULTS AND DISCUSSION}

\section{Morphological characteristics}

Based on morphological characters, the larvae collected from the four locations is $S$. frugiperda. It is recognized by the presence of four pinacula on the eighth terga forming a square, and a line forming an inverted Y shape on the head (Figure 1.A and 1.B). Detailed and illustrated steps from the key to immature noctuid by Godfrey (1987) on the morphological identification for larvae of $S$. frugiperda.

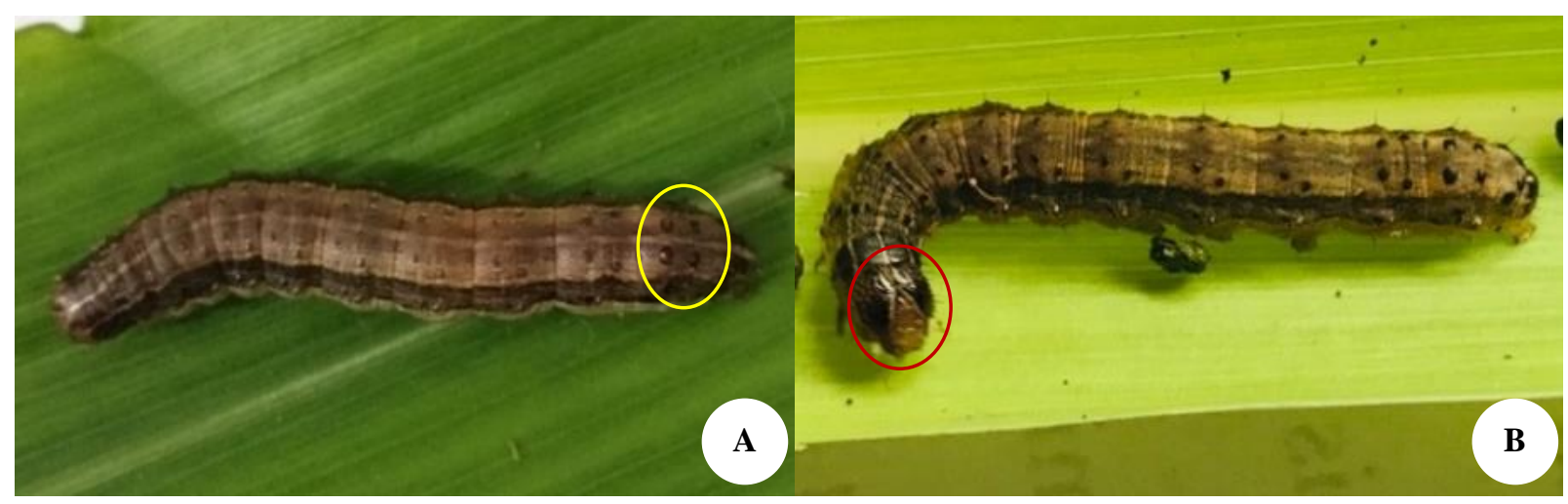

Figure 1. Spodoptera frugiperda obtained in Lampung; A. Pinacula forming a square on the eighth tergum; B. a line forming inverted Y shape on the head

\section{Key identification}

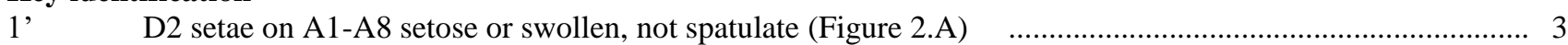

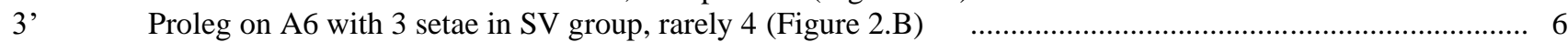

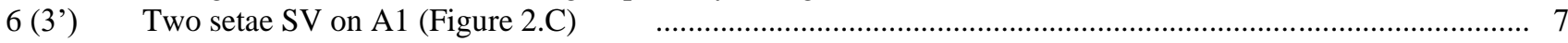

7' Subanal setae and median posterior anal setae unmodified (Figure 2.D) $\quad$................................................. 8

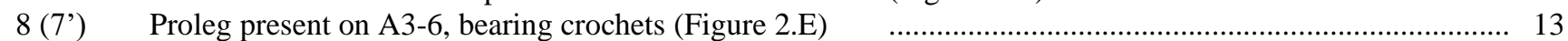

13 Body not with above combination of characters; if body transversely striped then head immaculate, freckled, reticulate, or with 3 or fewer contrasting spot associated with setal bases (Figure 2.F and 2.G) ....... 14

14' Body smooth or covered with the pavement (Figure 2.H), convex or conical granules, crochets A3-A6 proleg uniordinal (Figure 2.I) …............................................................................. 17

17 $\quad$ SD1 on A9 hairlike, weaker then D1, spiracular line when present (Figure 2.J) $\quad$...................................... 18

18 (17') Adfrontal ecdysial line not reaching epicranial notch, or distance from epicranial (Figure 2.G) $\quad$................ 19

19' T1 with 2 SD setae, one may be indicated merely by minute papilla (Figure 2.K) $\quad$..................................... 20

20, Not with the above combination of characters; distal region with thin spines and no medial, transverse cleft; or distal region with scattered stout spines or fringed; mandible with 4-12 teeth on cutting edge; inner surface with simple ridges or bearing 1-2 teeth various host associations (Figure 2.L) ..... 22

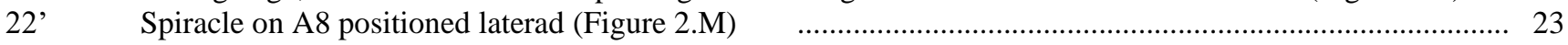

23, Mandible with 2 outer setae (Figure 2.N) $\quad$. . . .

26, Posterior margin of anal shield evenly convex, not lobed or tuberculate (Figure 2.O) $\quad$..................................28

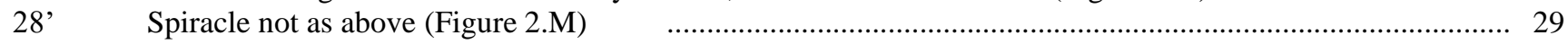

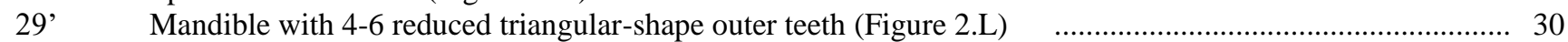

30' Two outer mandibular setae distantly spaced from each other (Figure 2.N) $\quad$............................................... 32

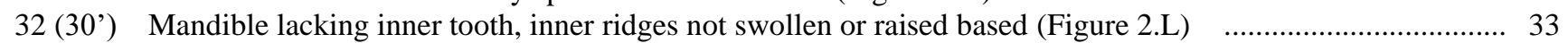

33' Spinneret short and broad, its length less than 2x its width, distal lip variable (Figure 2.P) ........................ 38

38 (33') Proximolateral spines of hypopharynx absent or inconspicuous (Figure 2.Q) .......................................... 39

39 (38) Midventral muscle attachments between prolegs on A3-A6 forming a Y (Figure 2.R) $\quad$................................ 40

40 (39) Pavement granules visible on dorsum of abdomen at 25X or more Spodoptera frugiperda (Figure 1) 

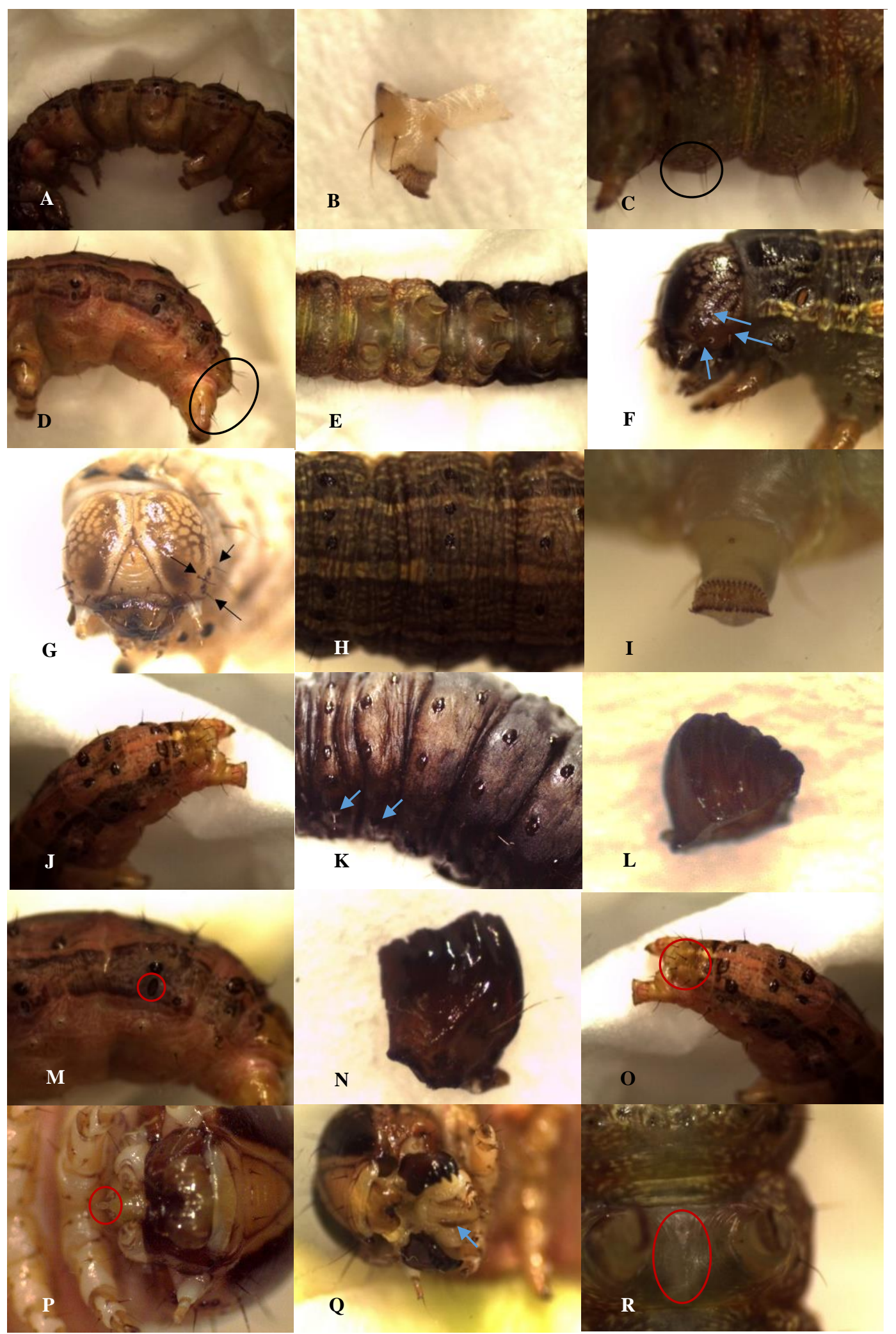

Figure 2. Morphology of Spodoptera frugiperda found in Lampung; A. Setae on A1-8 Setose; B. Four setae on proleg A6 C. Two setae SV on A1; 2D. Unmodified Subanal setae and median posterior analsetae; 2E. Proleg on A3-6 bearing crochets; $2 \mathrm{~F}$. Head with 3 contrasting spot associated with setal bases; $2 \mathrm{H}$. Body smooth or covered with the pavement; 2I. Crochets A3-A6 proleg uniordinal; $2 \mathrm{~J}$. SD1 on A9 hairlike, weaker then D1; 2K. Two setae on SD1; 2L. mandible with 4-12 teeth on cutting edge, inner surface with simle ridges and lacking inner teeth; 2M. Spiracle on A8 Laterad, not as above; 2N. Mandible with 2 setae distantly each other; $2 \mathrm{O}$. Anal shield evenly convex; 2P. Spinneret length less than 2x its width; 2Q Proximolateral spines of hypopharynx inconspicuous; $2 \mathrm{R}$. Midventral muscle attachments between prolegs on A3-A6 forming a Y. 


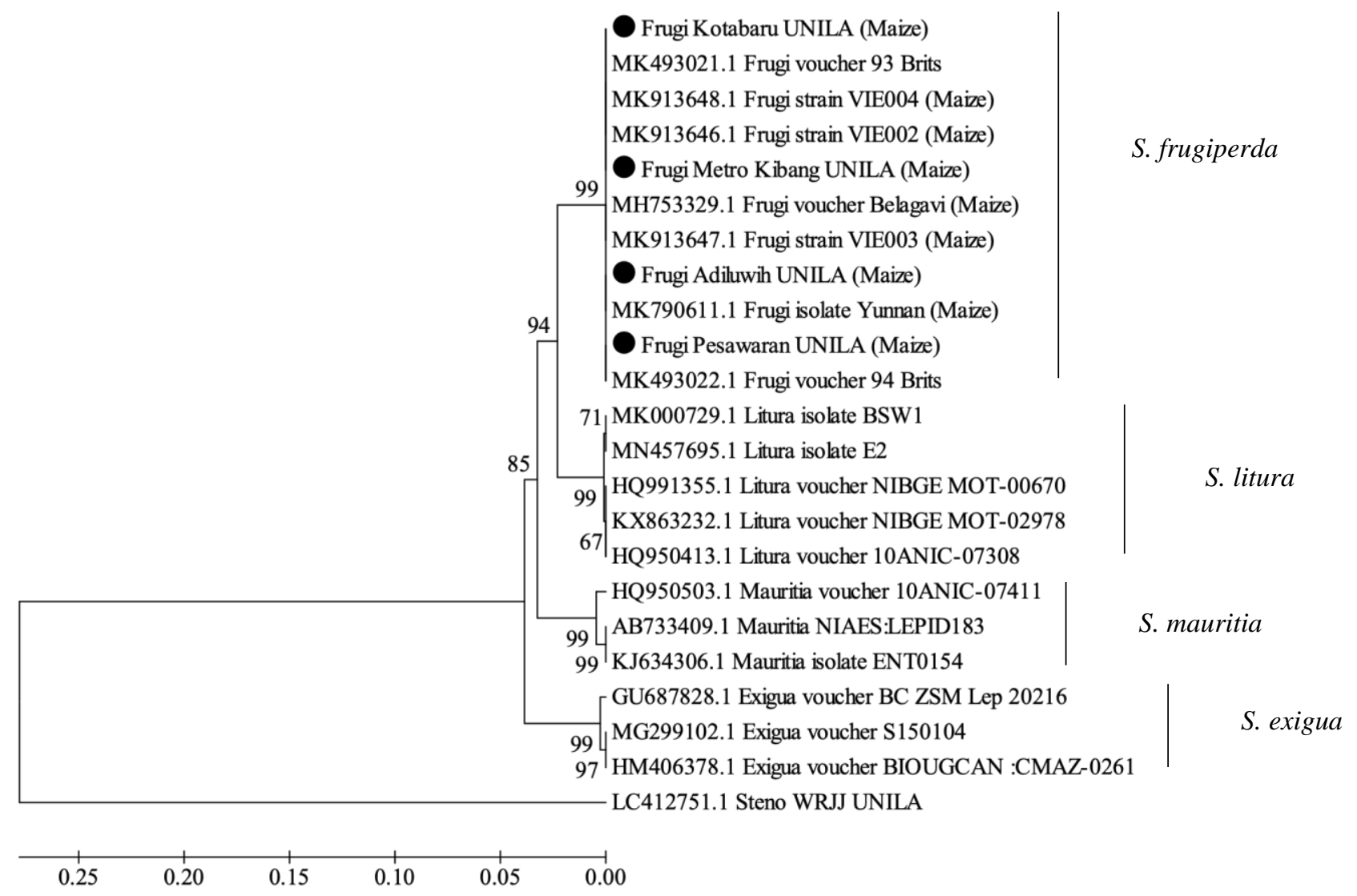

Figure 3. Dendrogram developed based on COI sequence analysis using UPGMA created using MEGA7 for windows (Kumar et al. 2016). Sequence of Stenocranus pasificus WRJJUNILA (Acc. no. LC412751.1) was used as outgroup. Some S. frugiperda sequences from other countries was also included, such as Kenya (voucher 93 Brits, Acc. no. MK493021.1 and voucher 94 Brits Acc. no. MK493022), Vietnam (VIE004, Acc. no. MK913648.1;VIE2, Acc. no. MK913646.1 and VIE 003 Acc. no. MK913647.1), India (voucher Belagavi, Acc. no. MH753329) and China (Yunnan, Acc. no. MK790611.1). : Spodoptera frugiperda obtained from Lampung

\section{Molecular analysis}

Sequence of DNA barcode region of Cytochrome c Oxidase Subunit I (COI) gene was used to confirm morphological identification. The result of BLAST revealed that all the samples obtained from Pringsewu, Pesawaran, Lampung Selatan and Lampung Timur has $100 \%$ similarity with S. frugiperda isolate C3 (Acc. no. MT103351.1). This result corresponds to that of BOLD. All the samples have $100 \%$ similarity to $S$. fugiperda.

The BLAST and BOLD result were confirmed by the dendrogram which was developed. All the samples were placed in the same group of $S$. frugiperda voucher 93 Brits (Acc. no. MK493021.1), VIE004 (Acc. no. MK913648.1), VIE002 (Acc. no. MK913646.1), voucher Belagavi (Acc. no. MH753329.1), VIE003 (Acc. no. MK913647.1), isolate Yunan (Acc. no. MK790611.1), voucher 94 Brits (Acc. no. MK493022.1) (Figure 3).

\section{Genetic diversity}

Based on the sequence analysis result of COI gene, all the S. frugiperda obtained from Lampung Province are identical to each other (100\% similarity). There is also no nucleotide variations observed within sequence of $S$. frugiperda from Kenya (voucher 93 Brits, Acc. no. MK493021.1 and voucher 94 Brits Acc. no. MK493022), Vietnam (VIE004, Acc. no. MK913648.1;VIE2, Acc. no. MK913646.1 and VIE 003 Acc. no. MK913647.1), India (voucher Belagavi, Acc. no. MH753329) and China (Yunnan, Acc. no. MK790611.1). The 100\% of similarity was also found in the sequence of S. frugiperda found in Lampung and from foreign countries which were added in this study. The Lampung isolates of $S$. frugiperda shared 95.22\% similarity with S. litura, $91.23 \%$ with S. exigua and $92.99 \%$ with $S$. mauritia (Table 1).

The DNA Barcode region of COI gene of S. frugiperda from Lampung have 29 nucleotides difference from $S$. litura isolate E2 (Acc no MN457695.1), 49 nucleotides difference as compared with S. exigua voucher S150104 (Acc. no. MG299102.1), and 43 nucleotides difference with S. mauritia voucher 10ANIC-07411 (Acc. no. HQ950503.1). 
Table 1. Similarity among Spodoptera frugiperda obtained from Lampung and other countries as well as with other Spodoptera genera

\begin{tabular}{|c|c|c|c|c|c|c|c|c|}
\hline & 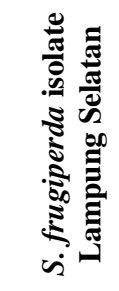 & 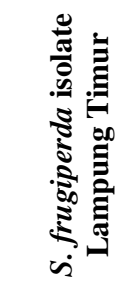 & 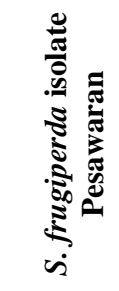 & 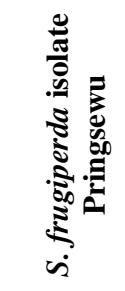 & 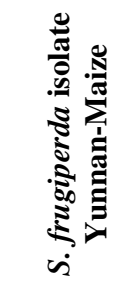 & 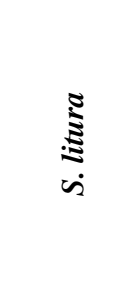 & 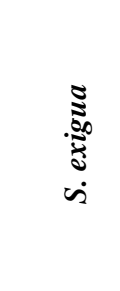 & 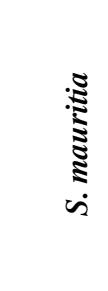 \\
\hline S. frugiperda Kotabaru-Indonesia & $100 \%$ & $100 \%$ & $100 \%$ & $100 \%$ & $100 \%$ & $95.22 \%$ & $91.93 \%$ & $92.99 \%$ \\
\hline S. frugiperda Metro Kibang-Indonesia & $100 \%$ & $100 \%$ & $100 \%$ & $100 \%$ & $100 \%$ & $95.22 \%$ & $91.93 \%$ & $92.99 \%$ \\
\hline S. frugiperda Pesawaran-Indonesia & $100 \%$ & $100 \%$ & $100 \%$ & $100 \%$ & $100 \%$ & $95.22 \%$ & $91.93 \%$ & $92.99 \%$ \\
\hline S. frugiperda Adiluwih-Indonesia & $100 \%$ & $100 \%$ & $100 \%$ & $100 \%$ & $100 \%$ & $95.22 \%$ & $91.93 \%$ & $92.99 \%$ \\
\hline S. frugiperda isolate Yunnan_Maize China & $100 \%$ & $100 \%$ & $100 \%$ & $100 \%$ & $100 \%$ & $95.22 \%$ & $91.93 \%$ & $92.99 \%$ \\
\hline S. litura isolate E2 Indonesia & $95.22 \%$ & $95.22 \%$ & $95.22 \%$ & $95.22 \%$ & $95.22 \%$ & $100 \%$ & $92.99 \%$ & $92.44 \%$ \\
\hline S. exigua voucher S150104-Canada & $91.93 \%$ & $91.93 \%$ & $91.93 \%$ & $91.93 \%$ & $91.93 \%$ & $92.99 \%$ & $100 \%$ & $90.88 \%$ \\
\hline S. mauritia voucher10ANIC-07411-Canada & $92.99 \%$ & $92.99 \%$ & $92.99 \%$ & $92.99 \%$ & $92.99 \%$ & $92.44 \%$ & $90.88 \%$ & $100 \%$ \\
\hline
\end{tabular}

Table 2. Plant damage caused by $S$. frugiperda observed in March 2019 in four districts of Lampung, Indonesia

\begin{tabular}{lc}
\hline District & Plant damage $(\boldsymbol{\%})$ \\
\hline Pringsewu & 72.3 \\
Pesawaran & 41.53 \\
Lampung Selatan & 26.50 \\
Lampung Timur & 79.12 \\
\hline
\end{tabular}

\section{Plant damage caused by $S$. frugiperda}

The absolute plant damage due to $S$. frugiperda invasion which was recorded in four districts was in the range of $26.50-70 \%$. This value was obtained from total of 20 plants which were chosen as plant samples within plots in each location. The lowest absolute plant damage was observed at Lampung Selatan, and the highest was observed at Lampung Timur (Table 2).

Field observation revealed that $S$. frugiperda laid the egg mass on the leaves surface (Figure 4). After hatching, larvae will attack leaves and move to the plant whorl. At 715 days after planting, the leaves attacked by $S$. frugiperda are looks transparent window-like (Figure 5.A). In the case of severe attack, it will cause hollow on the leaves (Figure 5.B) and ear (Figure 6.C). If the S. frugiperda attack in the plant whorl at 7-15 days after planting, it will cause plant death. S. frugiperda commonly found on the plant whorl at 15-30 days after planting (Figure 5.B).

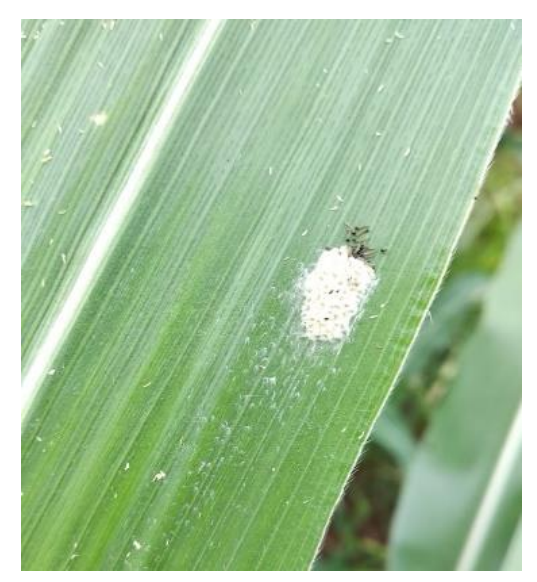

Figure 4. Larvae after hatched from egg mass on leaf surface

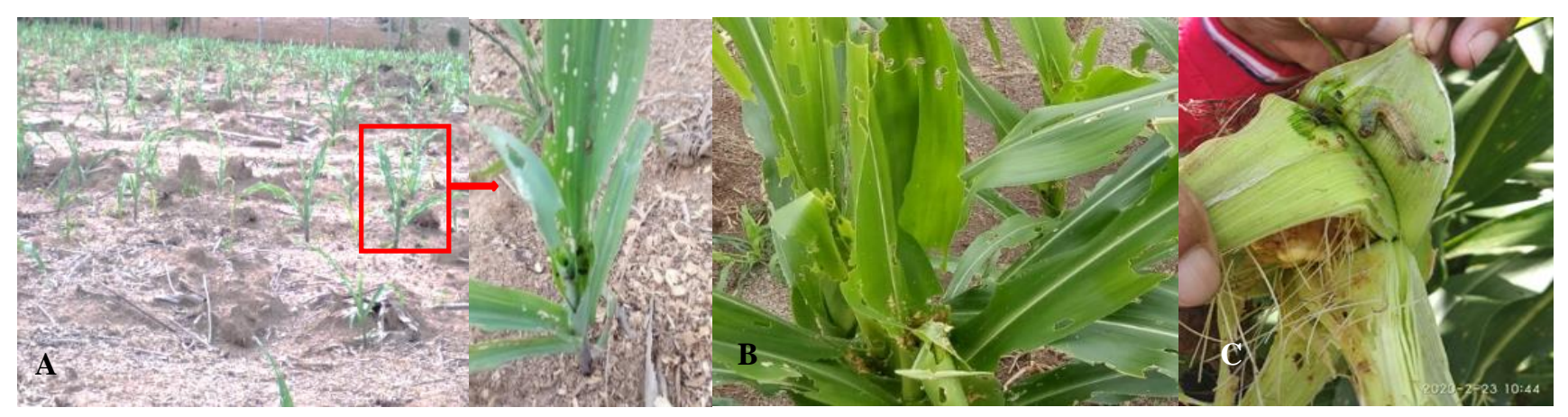

Figure 5. The symptom of plant attacked by S. frugiperda; A. Transparent windows-like on 14 days after planting; B. Hollow on leaves and broken plant whorl caused by Spodoptera frugiperda; C. S. frugiperda attacked on ear. 


\section{Discussion}

Based on morphological characteristics, the Spodoptera larvae obtained from Lampung Selatan, Lampung Timur, Pesawaran, and Pringsewu are S. frugiperda. The result of morphological identification was confirmed by the molecular analysis, since all the samples were placed in the S. frugiperda cluster. Thus, it is settled that the species identity of the larvae obtained in this study is $S$. frugiperda.

It has been reported that $S$. frugiperda has high genetic diversity (Belay et al. 2012). Genetic diversity is a level in biodiversity that refers to the amount of genetic variation in a species. Variation and genetic diversity are important to determine control strategies (Monnerat et al. 2006; Belay et al. 2012; Mahadeva-Swamy et al. 2018) and monitoring the development of resistance (Belay et al. 2012).

Using Amplified Fragment Length Polymorphism (AFLP), Clark et al. (2007) revealed that the majority of genetic variability of 23 populations of $S$. frugiperda from Mexico, United States, Puerto Rico, Brazil, and Argentina was within population and not between populations. Using the same method performed by Clark et al. (2007), Belay et al. (2012) reported genetic variations within 31 isolates of S. frugiperda collected from the United States, Argentina, Panama, and Puerto Rico. Through Random Amplification of Polymorphic DNA (RAPD), Monnerat et al. (2006) revealed significant genetic diversity among isolate $S$. frugiperda obtained from Mexico, Colombia, and Brazil. However, using ITS-1 region, Lewter et al. (2006) could not find any genetic variation within 17 individuals of $S$. frugiperda obtained from the United States.

This study revealed that using COI gene sequence analysis, we could not find any difference among $S$. frugiperda obtained in Lampung and also within reference to $S$. frugiperda from foreign countries used in this study. The Lampung isolates of $S$. frugiperda are also shared $100 \%$ similarity with reference of $S$. frugiperda from Kenya, Vietnam, India, and China. The fact that there was no genetic variability within Lampung isolates it might be caused by the number of samples which were used. In this study we work with the barcode region of $\mathrm{COI}$ gene from very small number of samples.

In order to obtained comprehensive results related to genetic diversity of $S$. frugiperda in Indonesia, the use of larger number of $S$. frugiperda sequences collected from other area in Indonesia is strongly recommended. Furthermore, additional analysis methods such as AFLP (Clark et al. 2007; Belay et al. 2012) and RAPD (Monnerat et al. 2006) may also be performed.

The fall armyworm $S$. frugiperda has a migratory behavior with a high dispersal capacity that allows the pest to quickly spread along with the range of its host plants (Kumela et al. 2018). S. frugiperda dispersed quickly because the adult can fly hundreds of kilometers per days (Early et al. 2018; Westbrook et al. 2015) with the help of the wind (Rose et al. 1975; Mitchell et al. 1991; Early et al. 2018; Westbrook et al. 2015). In 2018 it was reported in India (Sharanabasappa et al. 2018) and dispersed to Thailand and Myanmar (IPPC 2018). It has been reported that $S$. frugiperda prefers maize than the other host plants including cotton, soybean, and vegetables (Pitre et al. 1983; Hruska 2019).

In Lampung Province, S. frugiperda was initially observed in March 2019 causing severe damage to corn in the district of Pringsewu and Lampung Timur, mostly on young plants. As it is mentioned by Early et al. (2018), the $S$. frugiperda found in Lampung has very rapid spread. The invaded corn field increased more than $40 \%$ only in 2 weeks, from June 1, 2019, when it was found in 796 ha of cornfield, compared to 1337ha in June 15, 2019 (BPTPH 2019). Unfortunately, there are no reports on the total yield losses due to $S$. frugiperda in the Lampung Province. In Zimbabwe, plant damage caused by $S$. frugiperda can reach $26,4 \%-55,9 \%$ resulting in yield lost up to $11,57 \%$ (Baudron 2019). The damage on leaves, hair, and tufts at $25-50 \%$ reduces yield by $58 \%$ (Chimweta et al. 2019). In Brazil the yield loss caused by $S$. frugiperda reached $34 \%$, in certain varieties, furthermore, the loss could reach $57.6 \%$ (Cruz et al. 1999).

\section{ACKNOWLEDGEMENTS}

We do thanks to the University of Lampung, Indonesia for providing financial support. We are also very grateful to the Faculty of Agriculture, University of Lampung for letting us using research facilities during this study.

\section{REFERENCES}

Balla A, Bhaskar M, Bagade P, Rawal N. 2019. Yield losses in maize (Zea mays) due to fall armyworm infestation and potential IoT-based interventions for its control. J Entomol Zool Stud 7 (5): 920-927.

Baudron F, Zaman-Allah MA, Chaipa I, Chari N, Chinwada P. 2019. Understanding the factors influencing fall armyworm (Spodoptera frugiperda J.E. Smith) damage in African smallholder maize fields and quantifying its impact on yield. A case study in Eastern Zimbabwe. Crop Prot 120: 141-150.

Belay DK, Clark PL, Skoda SR, Isenhour DJ, Molina-Ochoa J, Gianni C, Foster JE. 2012. Spatial genetic variation among Spodoptera frugiperda (Lepidoptera: Noctuidae) sampled from the United States, Puerto Rico, Panama, and Argentina. Ann Entomol Soc Am 105 (2): 359-367.

BPTPH (Balai Proteksi Tanaman Pangan dan Hortikultura Provinsi Lampung). 2019. Laporan Tahunan Tahun 2019. Balai Proteksi Tanaman Pangan dan Hortikultura Provinsi Lampung. Bandar Lampung. [Indonesian]

Chimweta M, Nyakudyab IW, Jimua L, Mashingaidzec AB. 2019. Fall armyworm [Spodoptera frugiperda (J.E. Smith)] damage in maize: management options for flood-recession cropping smallholder farmers. Intl J Pest Manag. DOI: 10.1080/09670874.2019.1577514.

Chormule A, Shejawal N, Sharanabasappa, Kalleshwaraswamy CM, Asokan R Mahadeva-Swamy HM. 2019. First report of the fall Armyworm, Spodoptera frugiperda (J. E. Smith) (Lepidoptera, Noctuidae) on sugarcane and other crops from Maharashtra, India. J Entomol Zool Stud 7 (1): 114-117.

Clark PL, Molina-Ochoa J, Martinelli S, Skoda SR, Isenhour DJ, Lee DJ, Krumm JT, Foster JE. 2007. Population variation of the fall armyworm, Spodoptera frugiperda, in the Western Hemisphere. J Insect Sci 7 (5): 1-10.

Cruz I, Figueiredo MLC, Oliveira AC, Vasconcelos CA. 1999. Damage of Spodoptera frugiperda (Smith) in different maize genotypes cultivated in soil under three levels of aluminium saturation. Intl $\mathbf{J}$ Pest Manag 45: 293-296. 
Dumas P, Barbut J, Le Ru B, Silvain J-F, Clamens A-L, d'Alençon E. 2015. Phylogenetic molecular species delimitations unravel potential new species in the pest genus Spodoptera Guenée, 1852 (Lepidoptera, Noctuidae). PLoS ONE 10 (4): e0122407. DOI: 10.1371/journal.pone.0122407.

Early R, González-Moreno P, Murphy ST, Day R. 2018. Forecasting the global extent of invasion of the cereal pest Spodoptera frugiperda, the fall armyworm. NeoBiota 40: 25-50.

Folmer O, Black M, Hoeh W, Lutz R, Vrijenhoek R. 1994. DNA primers for amplification of mitochondrial cytochrome $\mathrm{c}$ oxidase subunit from diverse metazoan invertebrates. Mol Mar Biol Biotech 3 (5): 294-299.

Godfrey GL. 1987. Noctuidae (Noctuioidea). In Stehr FW (ed) Immature Insects. Kendal/Hunt Publishing Company, Dubuque, Iowa.

Goergen G, Kumar PL, Sankung SB, Togola A, Tamò M. 2016. First report of outbreaks of the fall armyworm Spodoptera frugiperda (J.E. Smith) (Lepidoptera, Noctuidae), a new alien invasive pest in west and central Africa. PloS ONE 11 (10): e0165632. DOI: 10.1371/journal. pone.0165632.

Groote HD, Kimenju SC, Munyua B, Palmas S, Kassie M, Bruce A. 2020 Spread and impact of fall armyworm (Spodoptera frugiperda J.E. Smith) in maize production areas of Kenya. Agr Ecosyst Environ 292 106804. DOI: 10.1016/j.agee.2019.106804.

Hall TA. 1999. BioEdit: A user-friendly biological sequence alignment editor and analysis program for Windows 95/98/NT. Nucl Acids Symp Ser 41: 95-98.

Hruska AJ. 2019. Fall armyworm (Spodoptera frugiperda) management by smallholders. CAB Rev 14 (043): 1-11.

Insecticide Resistance Action Committee. 2018. Integrated Pest Management (IPM) \& Insect Resistance Management (IRM) for Fall Armyworm in South African Maize. IRAC, South Africa.

IPPC. 2018. First detection of Fall Armyworm on the border of Thailand IPPC Official Pest Report, No THA-03/1. FAO: Rome, Italy.http://www/ippc.int/.

Kumar S, Tamura K, Stecher G. 2016. MEGA7: Molecular evolutionary genetics analysis version 7.0 for bigger datasets. Mol Biol Evol 33: 1870-1874

Kumela T, Simiyu J, Sisay B, Likhayo P, Mendesil E, Gohole L, Tefera T. 2018. Farmers' knowledge, perceptions, and management practices of the new invasive pest, fall armyworm (Spodoptera frugiperda) in Ethiopia and Kenya. Intl J Pest Manag 64: 1-9. DOI: 10.1080/09670874.2017.1423129.

Lewter JA, Szalanski AL, Nagoshi RN, Meagher RL, Owens JrCB, Luttrell RG. 2006. Genetic Variation within and between strains of the fall armyworm, Spodoptera frugiperda (Lepidoptera: Noctuidae) Fla Entomol 89 (1): 63-68

Lima MS, Silva PSL, Oliveira OF, Silva KMB, Freitas FCL. 2009. Corn yield response to weed and fall armyworm controls. Plant Daninha 28 (1): 103-111.

Luginbill P. 1928. The Fall Army Worm. Technical Bulletin. No. 3 United States Department of Agriculture, Washington DC

Mahadeva-Swamy HM, Asokan R, Kalleshwaraswamy CM, Sharanabasappa, Prasad YG, Maruthi MS, Shashank PR, Devi NI, Surakasula A, Adarsha, Srinivas A, Rao S, Vidyasekhar, Raju MS, Reddy GSS, Nagesh SN. 2018. Prevalence of "R" strain and molecular diversity of fall army worm Spodoptera frugiperda (J.E.Smith) (Lepidoptera: Noctuidae) in India. Indian J Entomol 80 (3): 544-553.

Maharani Y, Dewi VK, Puspasari LT, Rizkie L, Hidayat Y, Dono D. 2019. Cases of fall army worm Spodoptera frugiperda J. E. Smith (Lepidoptera: Noctuidae) attack on maize in Bandung, Garut and Sumedang District, West Java. J Cropsaver 2 (1): 38-46.

Mitchell ER, McNeiP JN, Westbrook JK, Silvain JF, Lalanne-Cassou B, Chalfant RB, Pair SD, WaddilP VH, Sotomayor-Rios A, Proshold FI.
1991. Seasonal periodicity of fall armyworm, (Lepidoptera: Noctuidae) in the Caribbean Basin and Northward to Canada. J Entomol Sci 26 (1): 39-50.

Monnerat R, Martins E, Queiroz P, Ordu'z S, Jaramillo G, Benintende G, Cozzi J, Real MD, Martinez-Ramirez A, Rausell C, Ceron J, Ibarra JE, Rincon-Castro MCD, Espinoza AM, Meza-Basso L, Cabrera L, Sanchez J, Soberon M, Bravo A. 2006. Genetic variability of Spodoptera frugiperda Smith (Lepidoptera: Noctuidae) populations from Latin America is associated with variations in susceptibility to Bacillus thuringiensis cry toxins. Appl Environ Microbiol 72 (11): 7029-7035.

Montezano DG, Specht A, Sosa-Gómez DR, Roque-Specht VF, SousaSilva JC, Paula-Moraes SV, Peterson JA, Hunt TE. 2018. Host plants of Spodoptera frugiperda (Lepidoptera: Noctuidae) in the Americas. Afr Entomol 26 (2): 286-300.

Nagoshi RN, Meagher RL. 2004. Seasonal distribution of fall armyworm (Lepidoptera: Noctuidae) host strains in agricultural and turf grass habitats. Environ Entomol 33 (4): 881-889.

Nonci N, Kalqutny SH, Mirsam H, Muis A, Azrai M, Aqil M. 2019. Pengenalan Fall Armyworm (Spodoptera frugiperda J.E. Smith) Hama Baru pada Tanaman Jagung di Indonesia. Badan Penelitian dan Pengembangan Pertanian Balai Penelitian Tanaman Serealia. Kementerian Pertanian, Jakarta. [Indonesian]

Pashley DP. 1986. Host-associated genetic differentiation in fall armyworm (Lepidoptera: Noctuidae): a sibling species complex? Ann Entomol Soc Am 79: 898-904.

Pashley DP. 1988. Quantitative genetics, development and physiological adaptation in host strains of fall armyworm. Evolution 42 (1): 93-102.

Pitre HN, Mulrooney JE, Hogg DDB. 1983. Fall armyworm (Lepidoptera: Noctuidae) oviposition: crop preferences and egg distribution on plants. J Econ Entomol 76: 463-466.

Prasanna BM, Huesing JE, Eddy R, Peschke VM. 2018. Fall Armyworm in Africa: A Guide for Integreted Pest Managemant. Cimmyt, Usaid.

Rose AH, Silversides RH, Lindquist OH. 1975. Migration flight by an aphid, Rhopalosiphum maidis (Hemiptera: Aphididae), and a Noctuid, Spodoptera frugiperda (Lepidoptera: Noctuidae). Can Ent 107: 567576.

Sharanabasappa, Kalleshwaraswamy CM, Asokan R, Mahadeva-Swamy HM, Maruthi MS, Pavithra HB, Hedge K, Navi S, Prabhu ST, Goergen G. 2018. First report of the fall armyworm Spodoptera frugiperda (JE Smith) (Lepidoptera: Noctuidae) an alien invasive pest on maize in India. Pest Manag Hortic Ecosyst 24 (1): 23-29.

Song XP, Liang YJ, Zhang XQ, Qin ZQ, Wei JJ, Li YR, Wu JM. 2020. Intrusion of fall armyworm (Spodoptera frugiperda) in sugarcane and its control by drone in China. Sugar Tech. DOI: 10.1007/s12355-02000799-x.

Srikanth J, Geetha N, Singaravelu B, Ramasubramanian T, Mahesh P, Saravanan L, Salin KP, Chitra N, Muthukumar M. 2018. First report of occurrence of fall armyworm Spodoptera frugiperda in sugarcane from Tamil Nadu, India. J Sugarcane Res 8 (2): 195-202.

Trisyono YA, Suputa, Aryuwandari VEB, Hartaman M, Jumari. 2019. Occurrence of heavy infestation by the fall armyworm Spodoptera frugiperda, a new alien invasive pest, in corn in Lampung Indonesia. Jurnal Perlindungan Tanaman Indonesia 23 (1): 156-160.

Westbrook JK, Nagoshi RN, Meagher RL, Fleischer SJ, Jairam S. 2015. Modeling seasonal migration of fall armyworm moths. Intl $\mathbf{J}$ Biometeorol. DOI: 10.1007/s00484-015-1022-x.

Yee KN, Aye MM, Htain NN, Oo AK, Kyi PP, Thein MM, Saing NN. 2019. First Detection Report of the Fall Armyworm Spodoptera frugiperda (Lepidoptera: Noctuidae) on Maize in Myanmar. https://www.ippc.int/static/media/files/pestreport/2019/01/11/Detectio $\mathrm{n}$ _report_of_FAW_in_Myanmar.pdf. 